\title{
Tutty Fruity Carrot by the Thermal Processing and Osmotic Dehydration - Standardization of Technology
}

\author{
Vinod Kumar.P ${ }^{1}$, Ms.Suneetha ${ }^{2}$, D.L Kusuma ${ }^{2}$, K.V Sucharitha ${ }^{3}$ \\ Department of Home Science, S.V University, Tirupati-517 502.
}

\begin{abstract}
Carrot is one of the most important staple vegetable. Carrots are known by champion scarlet horn, early gem, new red intermediate, long orange, half long scarlet and chant nary etc... carrot is a good source of Vitamin-A. And the most important elements are $\boldsymbol{\beta}$ - carotene, Alpha carotene and phytochemicals from these 3 elements are present in carrot and Therapeutics of carrot benefit the human health. The present study is an attempt to standardize the technology for developing vitamin- A rich carrot 'tutty fruity' through osmotic dehydration process using high sugar concentration and with intermittent thermal processing procedures such as blanching and hot air oven drying. Carrot tutty fruity developed was highly acceptable, as assessed from the organoleptic evaluation of the product by a group of trained panel members. Carrots are available throughout the year. It is easily digestible both as cooked and raw form and provides $\boldsymbol{\beta}$-carotene which is precursor for the synthesis of vitamin-A that prevents eye diseases and it is a food available at moderate cost. Carrot tutty fruity with its attractive colour can have great utilitarian value in desserts, confectioneries, sweets and special cuisine. Being a preserved food, tutty fruity has increased shelf life and does require refrigeration conditions for storage.
\end{abstract}

Key Words: Carrot, Therapeutics, Osmotic dehydration, Tutty fruity.

\section{Introduction}

Carrot is a Latin word meaning 'Burnt' and refers to the purple -red colour of the earlier cultivated forms. Carrot is an important member of root vegetable. The botanical name of carrot is "Daucus Carota" and it belongs to the family of "Umbelliferae". Among the root crops grown in India, carrot is one of the most popular among the common masses in India. Carrot is native to Asia. Its price remains fluctuating depending upon supply and demand, which range between Rs. 15 to Rs. 20 per /Kg carrot is grown in Asia for processing and fresh market use.

Carrot is a cool season crop, best adopted to areas with long, cool growing periods free from extremes of temperatures or moisture. The optimum average temperature suitable for growth of a healthy crop is between 16 and $20^{\circ} \mathrm{c}$ High temperatures in the later stages of plant growth may reduce yield, retard growth and produce a strong tasting coarse root.

In India, surveys carried out by the National Nutrition monitoring Bureau (NNMB) and integrated child development services (ICDS) indicate that prevalence of Bitot's spots in preschool children (1-5 years) ranges between 1-5 percent in different parts of the country. The corneal xeropthalmia has been reported to be 0.05-0.1 per 100 preschool children in south India. It is estimated that over 50,000 children become blind every year in India due to Vitamin-A deficiency. According to NNMB survey $0.04 \%$ of blindness in India is due to Vitamin - A deficiency which can be prevented.(Dietetics, 2002)

Carrot is a rich source of Vitamin-A and other sources rich in Vitamin-A and are green leafy vegetables, papaya, pumpkin etc and animal foods like eggs, milk and liver. Carrot contains appreciable amounts of thiamine, riboflavin and sugar. It is a good source of Vitamin $\mathrm{B}_{3}$, and carbohydrates. It is used both as raw and cooked vegetable, besides in preserves, pickles etc. Taste delicious 'Halwa' is also prepared from carrots. It is considered that darker the colour of carrot the higher nutritive value it has.

Since there are limited number of vegetable based tuity fruity products available in the market attempt has been made to develop a carrot tuity fruity. To this product eliminates the risk factors like Vitamin-A deficiency and chronic diseases such as cancer, heart diseases \& high blood pressure and also by its natural colour.So the product development with carrot increases B-carotene content for the synthesis of Vitamin-A. for this purpose and its attractive colour this product development.

\section{Materials And Methodology}

3.1) Procurement of raw materials:

The required raw materials used for carrot tuity fruity were carrots, sugar, citric acid and honey for variation. These raw materials were purchase from 'pasupathy' Super Market, Tirupati because it has been recognized as standard super market. 


\section{2) selection of plant materials :}

The roots of carrots used in the development of carrot tuity fruity was orange red in colour and immature with less yellow portion in the centre part of root. Selected carrot roots are fresh in appearance without any moisture loss on surface.

\section{3) Pre-Preparation and processing of raw materials:}

The fresh raw carrots may contain pesticide residues and some dust and other foreign materials. Hence carrots were thoroughly cleaned by washing and later peeled, cut and blanched. After proper selection and weighing, the surface dirt of carrot roots was removed by washing them in cold running water.Carrots were peeled to remove the surface hair and peeling increases the colour of carrot and also increases sugar absorption during osmosis process. Then the bottom and top edges were separated out. Now carrot was made into round pieces using sharp stainless steel knife and masher holes on carrot pieces were cut into cubes of $0.5^{*} 0.5 \mathrm{~cm}$ by using vegetable processor.

\section{Technical Processing Of Vegetable (Carrot):}

a)citric acid washing:

Citric acid solution was prepared for soaking the pieces for about 3-4 hours. Making small holes on carrot pieces increases the absorption of citric acid and sugar syrup. Citric acid acts as a preservative in carrot tuity fruity making.

\section{b) washing the cubes:}

The small cubes soaked in citric acid were washed for $3-4$ times under potable water.

\section{c) Blanching:-}

Thoroughly washed cubes of carrot were blanched for 5-7 minutes at $90^{\circ}$ with $1 \%$

$\mathrm{Nacl}_{2}$ (sodium chloride). Blanching process increases the colour and flavour of carrots and reduces microbial load.

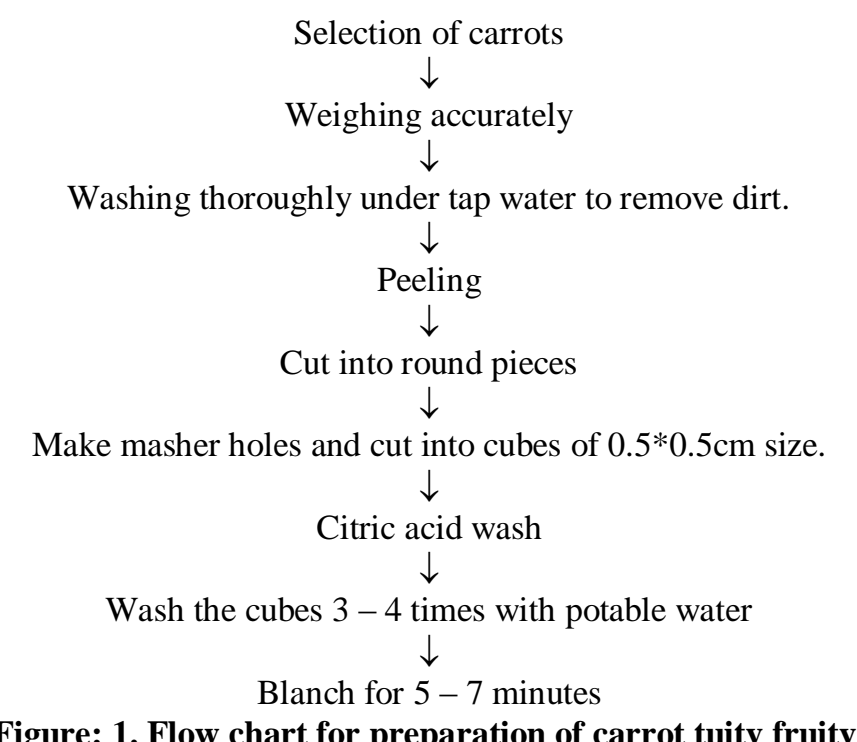

\section{4) preparation of sugar syrup:}

Sugar contains some foreign materials like dust, dirt etc. sugar is boiled at $90^{\circ}$ for minutes and filtered. Filtration removes all foreign materials from sugar syrup and soaked over - night.

\section{5) Drying and soaking:}

The next day, the syrup is drained from the carrot pieces and then the sugar syrup is heated to $50^{\circ} \mathrm{c}$ and soaking \& drying is repeated for $3-4$ times. This repeated soaking \& drying reduces the hardness of carrot tissues and increases the soft texture. Drying reduces the hardness of carrot cubes is carried under vacuum conditions i.e. Hot air over drying for 1 hour at $60^{\circ} \mathrm{c}$.

\section{6) formulation of product:}

For formulating the product various trials were worked out. Honey was used instead of sugar syrup and sun drying instead of over drying and the samples thus prepared were subjected to sensory evaluation. 
$\underline{\text { Table. No :-1 different trials made for formulating the product }}$

\begin{tabular}{|c|c|c|c|c|}
\hline s.no & Ingredients \& methods & Trial -I & Trial - II & Trial -III \\
\hline 1 & $\begin{array}{c}\text { Carrot pieces } \\
(\mathrm{g})\end{array}$ & 100 & 100 & 100 \\
\hline 2 & $\begin{array}{c}\text { Sugar for syrup } \\
(\mathrm{g})\end{array}$ & 200 & 200 & - \\
\hline 3 & $\begin{array}{c}\text { Citric acid } \\
(\mathrm{g})\end{array}$ & 3 & 3 & 3 \\
\hline 4 & $\begin{array}{c}\text { Sodium chloride } \\
(\mathrm{g})\end{array}$ & 1 & 1 & 1 \\
\hline 5 & $\begin{array}{c}\text { Honey } \\
(\mathrm{g})\end{array}$ & - & - & 250 \\
\hline 6 & Method of drying & $\begin{array}{c}\text { hot air oven drying } \\
\text { at } 60^{\circ} \mathrm{c}\end{array}$ & sun drying & $\begin{array}{c}\text { hot air oven drying } \\
\text { at } 60 \mathrm{c}\end{array}$ \\
\hline
\end{tabular}

Various trials were worked out to develop carrot tuity fruity. In the developed product, all the variations are done in laboratory and subjected to sensory evaluation. In this particular study, the already well established papaya tuity fruity was used as a reference sample.

\section{a) First Trial:}

In the first trial the tuity fruity was prepared with carrot by using sugar syrup and dried in hot air oven at $60{ }^{\circ} \mathrm{c}$ for 60 minutes and subjected to sensory evaluation. This trial was considered as the standard sample for the present study.

\section{b) Second Trial:}

In the second trial the tuity fruity was prepared with carrot by using sugar syrup and dried under sun for 90 minutes and subjected to sensory valuation.

\section{c) Third Trial:}

In this trial the tuity fruity was prepared with carrot by using Honey and dried in hot air oven at $60^{\circ} \mathrm{c}$ for 60 minutes and subjected to sensory evaluation.

\section{7) Method of preparation :-}

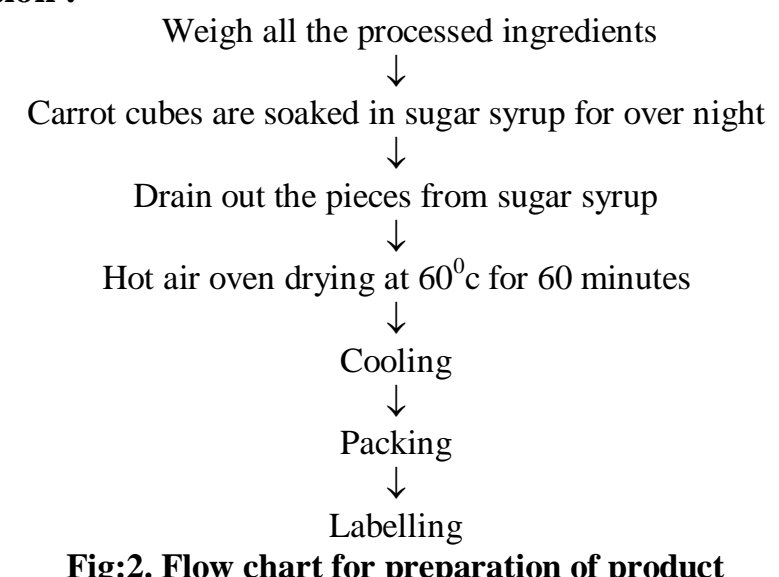

\section{8) sensory evaluation of the developed product:-}

Sensory analysis is concerned with measuring physical properties by psychological techniques. The characteristics of food materials are evaluated depending on the stimulus received when one is testing the material and which are measured and quantified. A stimulus may be defined as any chemical or physical activator, which causes response in a reactor.

Sensory evaluation can be defined as the quality of a product which is assessed by means of human sensory organs. This evaluation is called sensory (or) subjective (or) organoleptic. Every time food is eaten a judgment is made.

Sensory quality is a combination of different senses of perception coming into play in 
choosing and eating a food. Appearance, flavor and mouth feel decide the acceptance of the food. (Vijaya Khadar, 2003).

Sensory evaluation was conducted for all trials made to standardize the product. Sensory evaluation was an important part of the process of developing new food products and for analyzing the market potential for these foods. It is necessary in the study of processing and storage effects. The product which was standardized through the acceptability was evaluated techniques by 25 selected trained or semi trained panel members. The quality parameters such as appearance, colour, texture, taste, flavour and over all acceptability were carried out by panel of judges on a 5 point hedonic rating scale.

\section{9) Calculation of Nutritive Values:}

Calculation of nutritive value for each ingredient used in the development of the product is done with the help of Nutritive value of Indian foods by Gopalan et.al,(2005)

\subsection{0) Statistical Analysis:}

All the data is recorded and tabulated and subjected to appropriate statistical analysis. The difference between the acceptability of different prepared products were examined by student ' $t$ ' test for significant differences.

\section{RESULT AND DISCUSSION}

\section{1) Standardization of Ingredients for standardidzed product:}

In the standardization of truity fruity, carrot, sugar, citric acid is the most important factors. Three trials were done for developing the product. The variation between the trials is honey instead of sugar syrup and sun drying process is carried instead of hot air over drying.

Table no:- 3 Ingredients for the preparation of carrot tuity fruity.

\begin{tabular}{|clrcccc|}
\hline S.no & \multicolumn{2}{c}{ Ingredients } & Reference & T1 & T2 & T3 \\
1 & Carrots & $(\mathrm{g})$ & - & 100 & 100 & 100 \\
2 & sugar & $(\mathrm{g})$ & 200 & 200 & 200 & - \\
3 & Honey & $(\mathrm{g})$ & - & & - & 250 \\
4 & citric acid & $(\mathrm{g})$ & 3 & 3 & 3 & 1 \\
5 & sodium chloride $(\mathrm{g})$ & - & 1 & 1 & - \\
6 & Papaya & $(\mathrm{g})$ & 100 & - & - & - \\
7 & Colour & $(\mathrm{mg})$ & - & - & - & - \\
\hline
\end{tabular}

\section{2) Acceptability of tuity fruity:}

The acceptability of carrot tuity fruity was discussed with attributes. Based on the scores given by PG Students, the standardization is done.

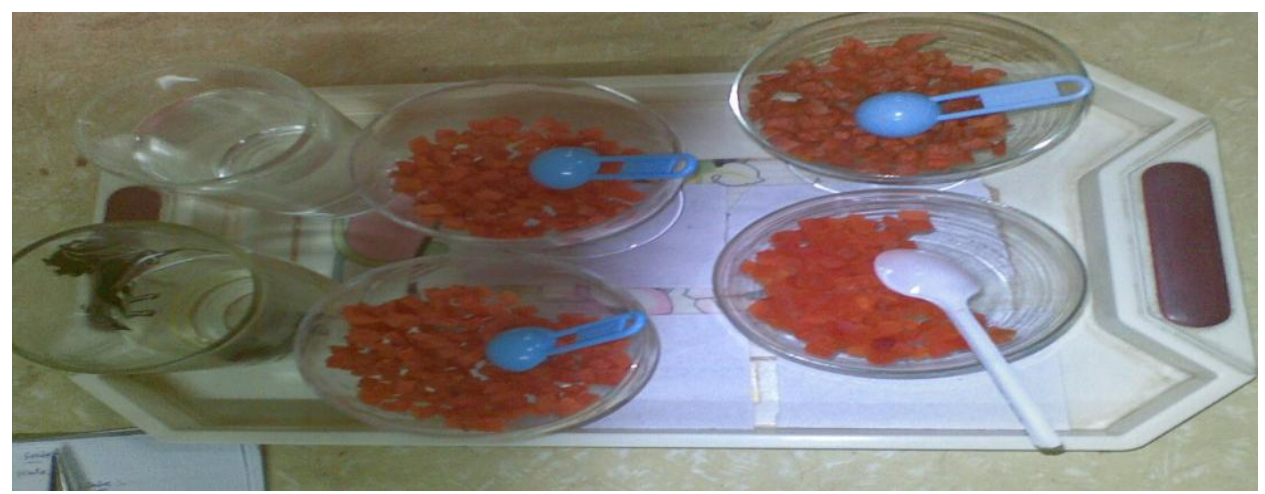

* Sensory evaluation of carrot tuity fruity.

\section{Apperance:}

The appearance of carrot tuity fruity was coded. The appearance which can be judged by eye colour, size and shape and absence of defects in food selection. 
Table no: 4. Mean scores of the appearance of the reference sample and carrot based tuity fruity.

\begin{tabular}{|l|l|l|l|l|l|}
\hline s.no & category of panel members & Reference & $\mathrm{T} 1$ & $\mathrm{~T} 2$ & $\mathrm{~T} 3$ \\
\hline 1 & & 4.68 & 3.68 & 3.76 & 2.4 \\
\hline
\end{tabular}

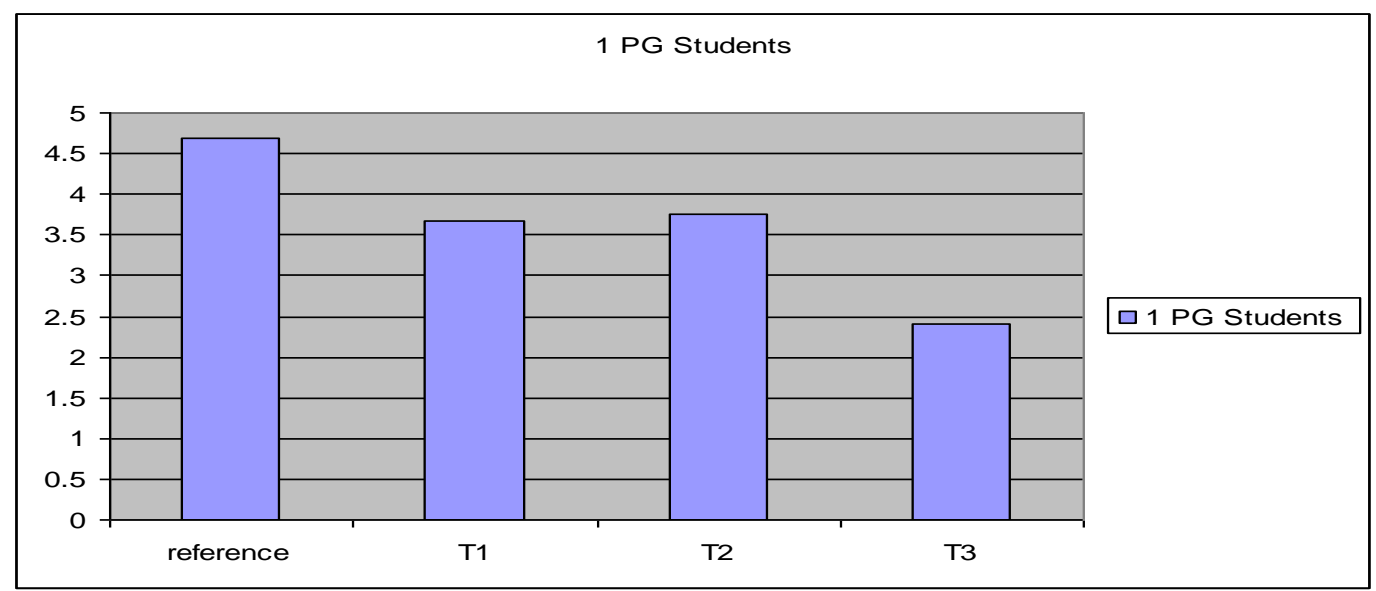

Fig: 3 Graphical mean scores for appearance of the tuity fruity

Note: R- Reference sample (papaya tuity fruity)

T1- Carrot tuity fruity (sugar syrup + Hot air oven dried)

T2-carrot tuity fruity (sugar syrup + sun dried)

T3-carrot tuity fruity (honey + hot air oven dried)

According to PG Students trial -2 has more appearance when compared to trial-3. T3 sample contains less score for appearance because honey colour dominates the colour of carrot. T2 has good appearance with appropriate size and shape of papaya tuity fruity (Reference)

Colour:

Colour has always played an important role in the life of man. It is an appearance property attribute to the spectral distribution of light.

Table no : 5 Mean scores of the colour of the reference sample and carrot based tuity fruity.

\begin{tabular}{|l|l|l|l|l|l|}
\hline \hline s.no & category of panel members & Reference & T1 & T2 & T3 \\
\hline 1 & PG Students & 4.64 & 3.84 & 3.86 & 2.16 \\
\hline
\end{tabular}

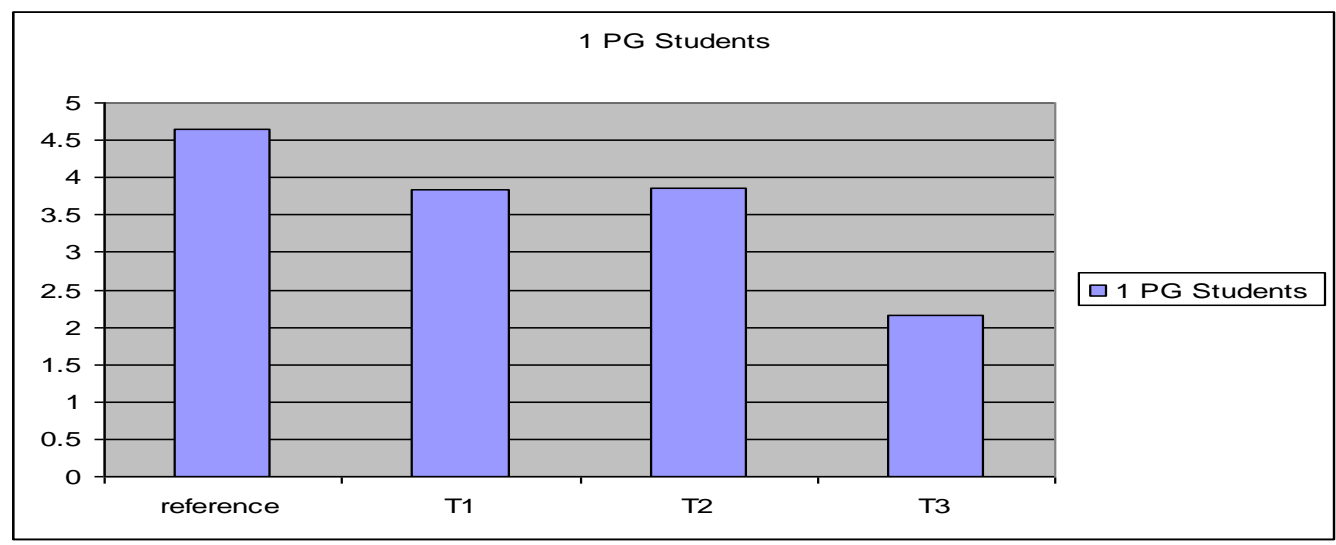

Fig.4: Graphical mean scores for colour of tuity fruity

Note: R- Reference sample (papaya tuity fruity)

T1- Carrot tuity fruity (sugar syrup + Hot air oven dried)

T2-carrot tuity fruity (sugar syrup + sun dried)

T3-carrot tuity fruity (honey + hot air oven dried) 
Regarding to PG Students, T1 has good when compared to T2 and T3. T1 has more retention of colour due to vacuum atmospheric conditions. T3 has some colour of honey hence it has less carrot colour. T2 has less colour when compared to $\mathrm{T} 1$ because under open atmospheric conditions some colour losses from carrots.

\section{Flavour :}

Flavour embraces the senses of taste, smell and falling in this study the flavour of the product was pleasant to raw flavour.

Table no:6 Mean scores of the flavour of the reference sample carrot based tuity fruity.
\begin{tabular}{|l|l|l|l|l|l|}
\hline s.no & category of panel members & Reference & T1 & T2 & T3 \\
\hline 1 & PG Students & 3.92 & 3.56 & 3.28 & 2.42 \\
\hline
\end{tabular}

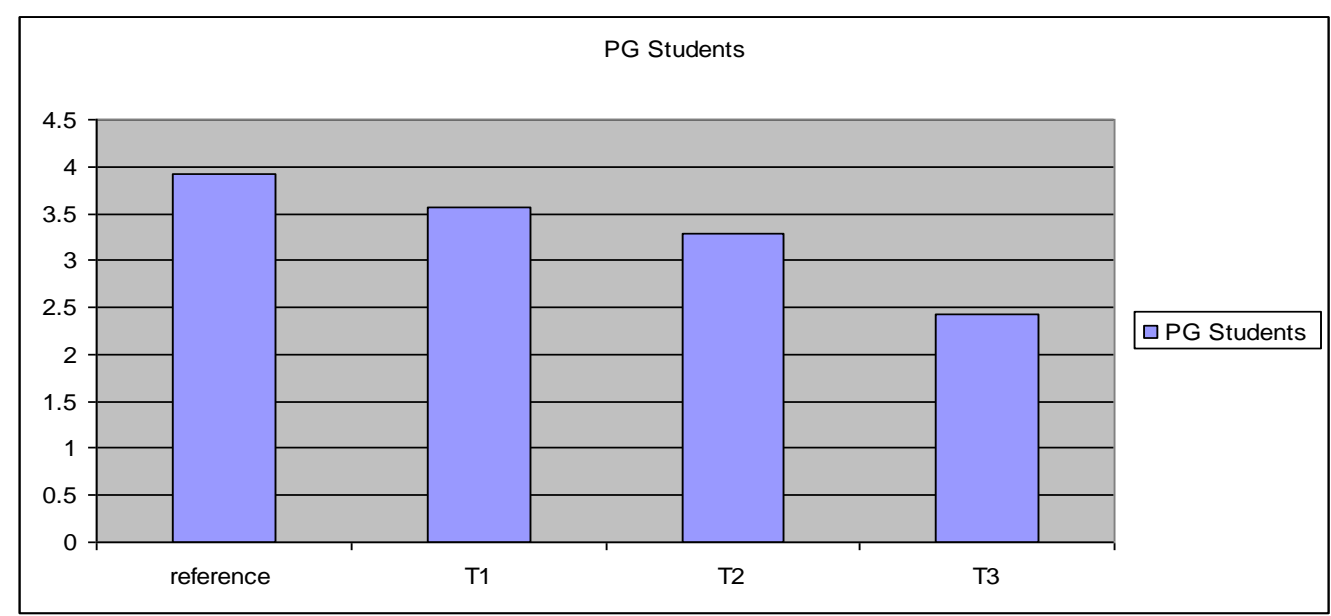

Fig: 5 Graphical mean scores for flavour of tuity fruity

Note: R- Reference sample (papaya tuity fruity)

T1- Carrot tuity fruity (sugar syrup + Hot air oven dried)

T2-carrot tuity fruity (sugar syrup + sun dried)

T3-carrot tuity fruity (honey + hot air oven dried)

Regarding to P.G.students, T1 has good flavour retention and T2 has some flavour loss, T3 has good flavour of honey but it is not accepted by most of the panel members. Under hot air oven conditions flavour is retended in T1. reference sample has good glavour of papaya.

\section{Taste:}

It is now well recognized characteristic of the sensory evaluation. In this product development the taste was coded pleasant to raw taste of tuity fruity.

Table no :7 Mean scores of the taste of the reference sample and carrot based tiuity fruity.

\begin{tabular}{|l|l|l|l|l|l|}
\hline \hline s.no & category of panel members & Reference & T1 & T2 & T3 \\
\hline 1 & PG Students & 4.32 & 3.68 & 3.6 & 2.48 \\
\hline
\end{tabular}

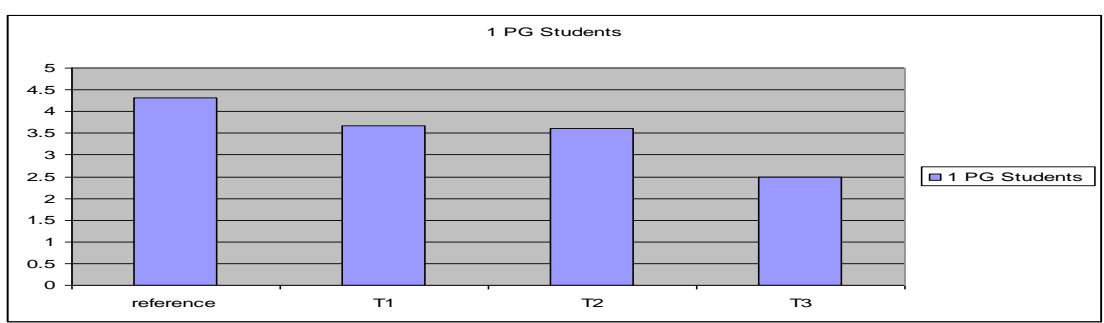

Fig: 6 Graphical mean scores for taste of tuity fruity

Note: R- Reference sample (papaya tuity fruity)

T1- Carrot tuity fruity (sugar syrup + Hot air oven dried)

T2-carrot tuity fruity (sugar syrup + sun dried)

T3-carrot tuity fruity (honey + hot air oven dried) 
according to PG Students, T1 has good taste of tuity fruity as reference sample. Sugar syrup based tuity fruity has more taste than honey based tuity fruity

\section{Texture:}

Texture of the product means consistency of the product in present study texture was coded. Enough soft to sticky texture.

\section{Table no: 8 Mean scores of the texture of the reference sample and carrot based tuity fruity}

\begin{tabular}{|l|l|l|l|l|l|}
\hline \multicolumn{1}{|c|}{ s.no } & category of panel members & Reference & T1 & T2 & T3 \\
\hline 1 & PG Students & 4.32 & 3.68 & 3.6 & 2.48 \\
\hline
\end{tabular}

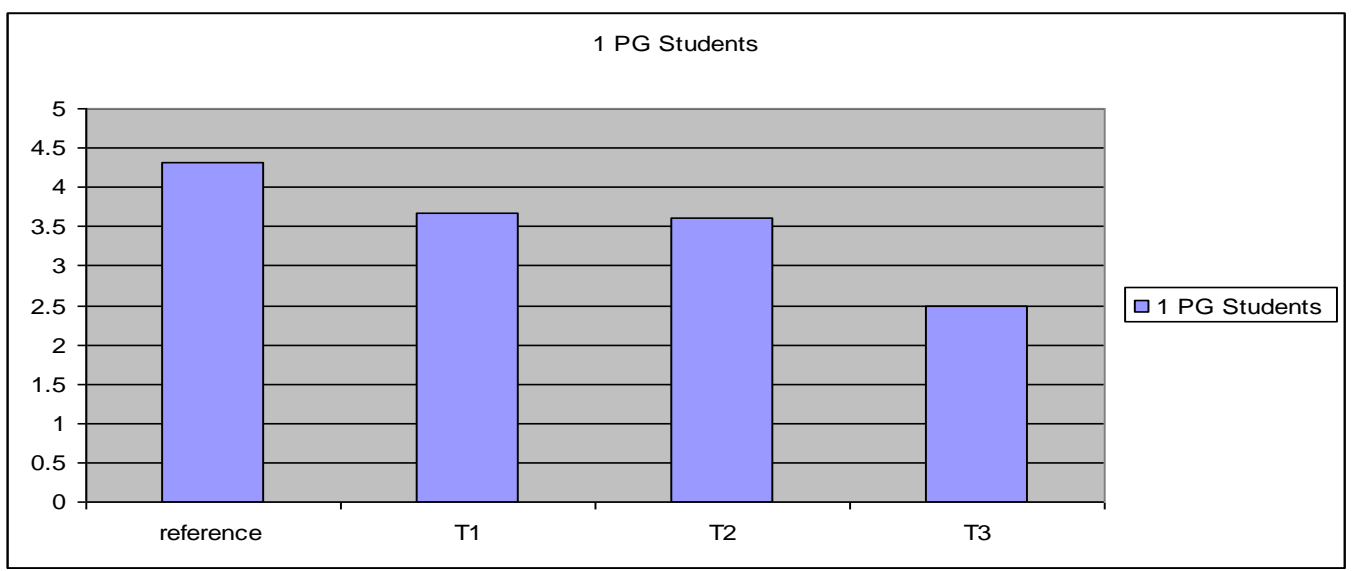

Fig: 7: Graphical mean scores for texture of tuity fruity

Regarding to PG students, reference has good texture. T1 has good texture when compared to T2. texture of the product is improved by repeated soaking sugar syrup and repeated drying process. T3 has less texture than T1 and $\mathrm{T} 2 . \mathrm{T} 1, \mathrm{~T} 2$, has less texture than reference sample.

\section{Overall acceptability:}

Table No: 9 Overall Acceptability Of The Trialed And Reference Tuity Fruity Samples By PG Students

\begin{tabular}{|c|c|c|c|c|c|}
\hline S.No & Category Of Panel Members & Reference & T1 & T2 & T3 \\
\hline 1 & PG Students & 4.4 & 3.8 & 3.76 & 2.52 \\
\hline
\end{tabular}

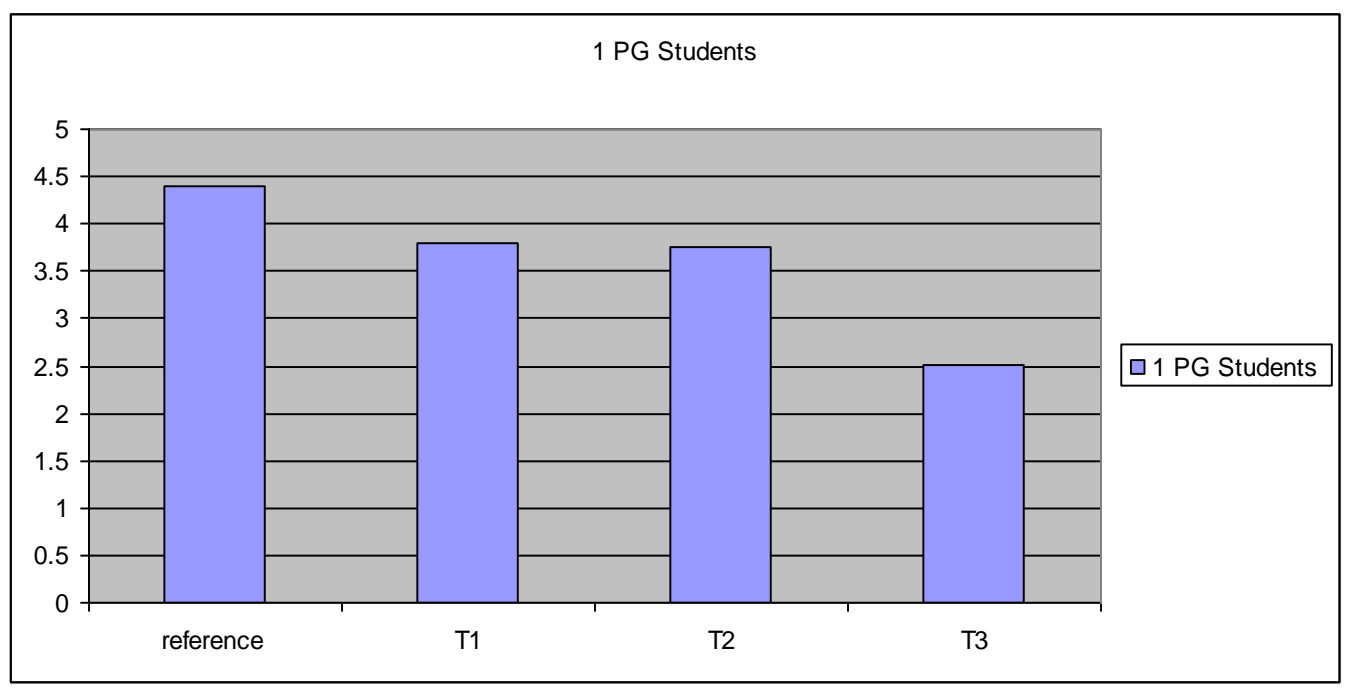

Fig:8 Graphical mean scores for over all acceptability of tuity fruity

Note: R- Reference sample (papaya tuity fruity)

T1- Carrot tuity fruity (sugar syrup + Hot air oven dried)

T2-carrot tuity fruity (sugar syrup + sun dried)

T3-carrot tuity fruity (honey + hot air oven dried) 
Regarding to PG Students. T1 has more overall acceptability than T2 and T3. From the above all sensory attributes T1 sample has good acceptability. This acceptability results were achieved through comparison of reference sample.

\section{3) calculation of Nutritive values:}

Calculation of Nutritive values for each Trial are given below.

Table no: 10 Nutritive value for carrot tuity fruity (Trial - i)

\begin{tabular}{|c|c|c|c|c|c|c|c|c|c|}
\hline s.no & $\begin{array}{c}\text { Name of } \\
\text { the } \\
\text { Ingridients }\end{array}$ & $\begin{array}{c}\text { Amount } \\
(\mathrm{g})\end{array}$ & $\begin{array}{c}\text { Moisture } \\
(\mathrm{g})\end{array}$ & $\begin{array}{c}\mathrm{CHO} \\
(\mathrm{g})\end{array}$ & Energy(K.cal) & $\begin{array}{c}\beta- \\
\text { Carotene( } \mu \mathrm{g})\end{array}$ & Calcium(mg) & Phosphorus(mg) & $\begin{array}{c}\text { Iron } \\
(\mathrm{mg})\end{array}$ \\
\hline 1 & carots & 100 & 86 & 10.6 & 48 & 1890 & 80 & 530 & 1.03 \\
\hline 2 & $\begin{array}{c}\text { sugar } \\
\text { syrup } \\
\text { (absorbed) }\end{array}$ & $100 \mathrm{ml}$ & 0.4 & 99.4 & 398 & - & 12 & 1 & 0.155 \\
\hline
\end{tabular}

\begin{tabular}{|c|c|c|c|c|c|c|c|c|c|}
\hline s.no & $\begin{array}{c}\text { Name of } \\
\text { the } \\
\text { Ingridients }\end{array}$ & $\begin{array}{c}\text { Amount } \\
(\mathrm{g})\end{array}$ & $\begin{array}{c}\text { moisture } \\
(\mathrm{g})\end{array}$ & $\mathrm{CHO}(\mathrm{g})$ & energy(K.cal) & $\begin{array}{c}\beta- \\
\text { carotene }(\mu \mathrm{g})\end{array}$ & calcium(mg) & phosphorus(mg) & $\begin{array}{c}\text { Iron } \\
(\mathrm{mg})\end{array}$ \\
\hline 1 & carots & 100 & 86.0 & 10.6 & 48 & 1,890 & 80 & 530 & 1.03 \\
\hline 2 & $\begin{array}{c}\text { sugar syrup } \\
\text { (absorbed) }\end{array}$ & $100 \mathrm{ml}$ & 0.4 & 99.4 & 398 & - & 12 & 1 & 0.155 \\
\hline
\end{tabular}

\begin{tabular}{|c|c|c|c|c|c|c|c|c|c|}
\hline Table no: 12 Nutritive value for developed products( Trial-iii) \\
\begin{tabular}{|c|c|c|c|c|c|c|}
\hline s.no \\
Ingridients
\end{tabular} & $\begin{array}{c}\text { Name of } \\
(\mathrm{g})\end{array}$ & $\begin{array}{c}\text { moisture } \\
(\mathrm{g})\end{array}$ & $\mathrm{CHO}(\mathrm{g})$ & energy(K.cal) & $\begin{array}{c}\beta- \\
\text { carotene }(\mu \mathrm{g})\end{array}$ & calcium $(\mathrm{mg})$ & phosphorus $(\mathrm{mg})$ & $\begin{array}{c}\text { Iron } \\
(\mathrm{mg})\end{array}$ \\
\hline 1 & carots & 100 & 86.0 & 10.6 & 48 & 1,890 & 80 & 530 & 1.03 \\
\hline 2 & $\begin{array}{c}\text { Honey } \\
\text { (absorbed) }\end{array}$ & $100 \mathrm{ml}$ & 20.6 & 77.5 & 319 & - & 5 & 16 & 0.696 \\
\hline
\end{tabular}

\section{4) comparison of the nutritive value of reference and carrot tuity fruity:}

\section{Carrot tuity fruity:}

In the present study energy, carbohydrates, moisture, calcium, phosphorus, $\beta$-cartone, Iron were calculated buy using "Nutritive value of Indian foods" (Gopalan, 2005)

Table no :13 comparison of the Nutritive value of carrot tuity fruity with reference

\begin{tabular}{|c|c|c|c|c|c|c|c|c|c|}
\hline $\begin{array}{c}\text { s.n } \\
0\end{array}$ & $\begin{array}{l}\text { Name of } \\
\text { the } \\
\text { Ingridien } \\
\text { ts }\end{array}$ & $\begin{array}{c}\text { Amou } \\
\text { nt (g) }\end{array}$ & $\begin{array}{c}\text { moistur } \\
\text { e (g) }\end{array}$ & $\begin{array}{c}\mathrm{CHO}( \\
\mathrm{g})\end{array}$ & $\begin{array}{c}\text { energy }(\mathrm{K} . \mathrm{c} \\
\mathrm{al})\end{array}$ & $\begin{array}{c}\beta- \\
\text { carotene(1 } \\
\text { g) }\end{array}$ & $\begin{array}{c}\text { calcium }(\mathrm{m} \\
\mathrm{g})\end{array}$ & $\begin{array}{c}\text { phosphorus(m } \\
\text { g) }\end{array}$ & $\begin{array}{l}\text { Iron } \\
(\mathrm{mg})\end{array}$ \\
\hline 1 & $\begin{array}{c}\text { reference } \\
\text { sample }\end{array}$ & 100 & 91.2 & 106.6 & 430 & 666 & 29 & 14 & $\begin{array}{c}0.65 \\
5\end{array}$ \\
\hline 2 & $\begin{array}{c}\text { sample - } \\
\text { I }\end{array}$ & 100 & 86.4 & 110 & 446 & 1,890 & 92 & 531 & $\begin{array}{c}1.18 \\
5\end{array}$ \\
\hline 3 & $\begin{array}{c}\text { sample - } \\
\text { II }\end{array}$ & 100 & 86.4 & 110 & 446 & 1,890 & 92 & 531 & $\begin{array}{c}1.18 \\
5\end{array}$ \\
\hline 4 & $\begin{array}{c}\text { sample - } \\
\text { III }\end{array}$ & 100 & 106.6 & 90.1 & 367 & 1,890 & 83 & 546 & $\begin{array}{c}1.72 \\
6\end{array}$ \\
\hline
\end{tabular}

Note: Reference sample (papaya tuity fruity)

Sample - I - carrot tuity fruity (sugar syrup + Hot air oven dried)

Sample - II - carrot tuity fruity (sugar syrup + sun dried)

Sample - III - carrot tuity fruity (honey + hot air oven dried)

Carrot tuity fruity with honey (sam -III) contains more moisture content than sample I and II i.e.106.6g Sample - I and II has good sources of carbhohydrates than sample - III i.e $110.0 \mathrm{~g}$

Sample - I and Sample-II also contains more energy than sapmle - III i.e.446 K.cal. All the samples are good sources of $\beta$-Carotene content because the basic ingredient in these three samples is carrot i.e. $1,890 \mu \mathrm{g}$

Sample - III consists more phosphorus and Iron than sample I \& II i.e. $546 \mathrm{mg} .1 .726 \mathrm{mg}$ respectively but sample I \& II contains high amount of calcium when compared to sample III i.e. $92 \mathrm{mg}$ 


\section{SUMMARY AND CONCLUSION}

The summary study entitled "Tuity fruity with carrots by osmotic dehydration"(standardization of technology)with the objective to study the acceptability of the developed product by subjecting to sensory evaluation.Three trials were carried out to standardize the product. Sensory evaluation was conducted for all trials by using 5 - point hedonic rating scale with 25 members of PG students and these results are calculated by using statistical formulas.Nutritive values were calculated with the help of the book "Nutritive values of Indian Foods". The carrot tuity fruity was packed in polythene covers and labelled to appropriately. The developed product is rich in $\boldsymbol{\beta}$ - carotene content and it is colourful and attractive to all age groups. Carrot is an important vegetable. This vegetable is available throughout the year. This product requires less ingredients i.e. only two (carrot, sugar). The cost of the product is less . this is suitable for all types of income groups. Processing cost also is less for carrot tuity fruity preparation.From this present study, the fruity with vegetable instead of fruits can change the food habits in India. Generally carrots have good nutritive values and some anti carcinogenic, antiarthitic $\&$ antioxidant properties. Tuity fruity with carrots gives variety to the garnishing dishes like cakes, cookies, ice creams, pastries etc.The carrot tuity fruity gives more $\beta$-carotene content (i.e. 1,890 $\mu \mathrm{g}$ ) for the synthesis of Vitamin -A and to prevent Vitamin-A deficiency in Pre - school children and also improve skin health.Carrot tuity fruity is more stable to deterioration at room temperatures and stored at normal room conditions for 6- months without any cool conditions. Tuity fruity is one of the preserved product prepared for decorating cookies, desserts etc. So the present study with these main objectives was carried out.

\section{Bibliography}

[1]. Prof. Aman .D (1969), Medical secrets of your food, indo American Hospital Trust, Bangalore - Mysore, Page No: 446.

[2]. Cridy Fietch, American journal of Clinical Nutirtion, Volume - 78, No.2 Aug (2003), American society of Clinical Nutrition.

[3]. Gopalan E, Rama Sastri B.V., and S.C Balasubramaniam (2002), "Nutritive Value of Indian Foods", NIN, ICMR, Hyderabad.

[4]. Journal of food process Engineering, Volume- 29, no-6, December-2006, P.P 592-614(23).

[5]. Sri Lakshmi.B, "Dietetics" (2002), New age international (p) Ltd, New Delhi.

[6]. Sri Lakshmi.B, "Food Science" (2005), New age international (P) Ltd, New Delhi.

[7]. N.Shakuntala Manay, M.Shadaksharaswamy(1998). "Foods Facts and Principles", New age international (P) Limited Publishers, New Delhi.

[8]. Goodwin.T.E. "The Biochemistry of carotenoids", Volumes I \& II Academic Press, New York, 1980.

[9]. Vijaya Khadar (2005), “Food Science and Technology" New Age International (P) Limitd Publishers, New Delhi.

[10]. William. J, R.E.Eakin, E.Beersteeker, (Jr) and W.Shine, The Biochemistry of vitamins, Reinhold, New York, 1950 